\title{
Prototype Foamy Virus Integrase Displays Unique Biochemical Activities among Retroviral Integrases
}

\author{
Anthony J. Rabe ${ }^{1}$, Yow Yong Tan ${ }^{1}$, Ross C. Larue ${ }^{1,2}$ and Kristine E. Yoder ${ }^{1,2,3, *}$ \\ 1 Department of Cancer Biology and Genetics, The Ohio State University College of Medicine, \\ Columbus, OH 43026, USA; rabe.48@osu.edu (A.J.R.); yowyong816@gmail.com (Y.Y.T.); \\ larue.22@osu.edu (R.C.L.) \\ 2 Center for Retrovirus Research, The Ohio State University, Columbus, OH 43026, USA \\ 3 Comprehensive Cancer Center, The Ohio State University, Columbus, OH 43026, USA \\ * Correspondence: kristine.yoder@osumc.edu
}

Citation: Rabe, A.J.; Tan, Y.Y.; Larue, R.C.; Yoder, K.E. Prototype Foamy Virus Integrase Displays Unique Biochemical Activities among Retroviral Integrases. Biomolecules 2021, 11, 1910. https://doi.org/ 10.3390/biom11121910

Academic Editor: Philippe Urban

Received: 18 November 2021 Accepted: 17 December 2021 Published: 20 December 2021

Publisher's Note: MDPI stays neutral with regard to jurisdictional claims in published maps and institutional affiliations.

Copyright: (c) 2021 by the authors. Licensee MDPI, Basel, Switzerland. This article is an open access article distributed under the terms and conditions of the Creative Commons Attribution (CC BY) license (https:// creativecommons.org/licenses/by/ $4.0 /)$.

\begin{abstract}
Integrases of different retroviruses assemble as functional complexes with varying multimers of the protein. Retroviral integrases require a divalent metal cation to perform one-step transesterification catalysis. Tetrameric prototype foamy virus (PFV) intasomes assembled from purified integrase and viral DNA oligonucleotides were characterized for their activity in the presence of different cations. While most retroviral integrases are inactive in calcium, PFV intasomes appear to be uniquely capable of catalysis in calcium. The PFV intasomes also contrast with other retroviral integrases by displaying an inverse correlation of activity with increasing manganese beginning at relatively low concentrations. The intasomes were found to be significantly more active in the presence of chloride co-ions compared to acetate. While HIV-1 integrase appears to commit to a target DNA within $20 \mathrm{~s}$, PFV intasomes do not commit to target DNA during their reaction lifetime. Together, these data highlight the unique biochemical activities of PFV integrase compared to other retroviral integrases.
\end{abstract}

Keywords: integrase; retrovirus; prototype foamy virus; divalent cation

\section{Introduction}

Retroviruses require reverse transcription and integration to complete the viral life cycle [1]. Reverse transcriptase copies the viral genomic RNA to a linear double-stranded DNA (cDNA). Integrase (IN) acts on the viral cDNA with two necessary catalytic activities: terminal cleavage and strand transfer. Terminal cleavage, also called $3^{\prime}$ end processing, is the removal of two nucleotides from the $3^{\prime}$ ends of nascent reverse transcripts yielding recessed $3^{\prime}$ hydroxyls. Strand transfer is the covalent joining of these $3^{\prime}$ hydroxyls to the host DNA. The $3^{\prime}$ ends are joined across one major groove of host DNA with $4-6$ base pairs of intervening host sequence. The product of IN activities in vivo is the integrated provirus flanked by $4-6$ base gaps of the host sequence and $5^{\prime}$ dinucleotide flaps of the viral sequence. The integration intermediate is likely repaired by host DNA repair enzymes [2]. Retroviral IN may also catalyze intramolecular strand transfer, termed autointegration. This phenomenon effectively ends a cellular infection and may also appear during biochemical assays. Half site integration (HSI) products where a single viral DNA is joined to a target DNA have also been observed in vitro. It is unclear if these aberrant integration products occur under normal conditions in vivo, although observed altered integration sites suggest they may occur with mutant IN or in the presence of suboptimal concentrations of clinically relevant IN strand transfer inhibitors $[3,4]$.

Retroviral INs catalyze $3^{\prime}$ processing and strand transfer by single step transesterification chemistry [5-7]. Each step may be independently assayed with DNA oligomers mimicking blunt viral cDNA ends (vDNA) to test $3^{\prime}$ processing or preprocessed vDNA to test strand transfer. These enzymes do not require an energetic co-factor such as adenosine 
triphosphate (ATP) [8]. INs have a conserved aspartate, aspartate, glutamate (DDE) motif that coordinates two divalent metal ions. IN and similar enzymes, including transposases, have been characterized for their use of metal cations. Magnesium $(\mathrm{Mg})$ and calcium $(\mathrm{Ca})$ are the most abundant of these cations in a cell, but $\mathrm{Ca}$ is more highly regulated within cellular compartments [9]. Similar to $\mathrm{Mg}, \mathrm{Ca}$ is often able to bind the catalytic site of enzymes, but is unable to support catalysis $[9,10]$. The reason for enzymatic inactivity or altered activity with $\mathrm{Ca}$ is unclear and several hypotheses have been postulated, including variation in ion size or coordination number [9-16]. Manganese (Mn) is less abundant than $\mathrm{Mg}$, but enzymes are often able to employ this cation for catalysis [10,15,17]. Although enzymes may be active with $\mathrm{Mn}$, the activity may be altered from that observed with $\mathrm{Mg}$, such as less stringent sequence specificity $[11,12,16,18]$

Human immunodeficiency virus (HIV-1) IN was characterized for its ability to assemble with vDNA, perform $3^{\prime}$ processing, or catalyze strand transfer to a target DNA in the presence of $\mathrm{Mn}, \mathrm{Mg}, \mathrm{Ca}$, cobalt (Co), or no cation [19]. These results revealed that HIV-1 IN may assemble an integration complex in the presence of Ca but cannot complete $3^{\prime}$ processing or strand transfer. HIV-1 IN assembled with vDNA in the presence of $\mathrm{Ca}$ could perform enzymatic activities when $\mathrm{Mg}$ or $\mathrm{Mn}$ were added. This observation has been fundamental for the recent advances in the assembly and purification of stable retroviral intasomes, including HIV-1 and mouse mammary tumor virus (MMTV) [20,21]. Purified IN combined with vDNA oligomers in the presence of Ca can form intasomes, the multimeric IN complex. The intasomes are stable for purification by size exclusion chromatography and do not perform catalysis. This strategy allows for the precise control of catalytic activity with later addition of $\mathrm{Mg}$ to purified intasomes. Interestingly, prototype foamy virus (PFV) intasomes do not require the presence of a divalent cation for assembly [22,23].

Previous studies using monomeric protein suggested HIV-1 IN and avian sarcoma virus (ASV) IN displayed greater catalytic activity in the presence of Mn compared to Mg [24]. Similarly, PFV IN was shown to have greater strand transfer activity yielding more HSI and CI products in the presence of Mn but only with a blunt vDNA, suggesting that Mn stimulated $3^{\prime}$ processing activity [25]. However, HSI and CI with a preprocessed vDNA were equal in the presence of Mn or Mg. These data indicate that PFV IN 3' processing is more active in the presence of $\mathrm{Mn}$, but strand transfer is not. As seen with IN from other retroviruses, PFV IN was inactive in the presence of Ca and a blunt vDNA indicating it was unable to perform $3^{\prime}$ processing [25]. PFV IN displayed an unexpected ability to perform strand transfer generating HSI products with preprocessed vDNA in the presence of $\mathrm{Ca}$. This suggested PFV IN can perform assembly and strand transfer in the presence of $\mathrm{Ca}$, but not $3^{\prime}$ processing. It was unclear whether intasomes would display similar results in the presence of these divalent metal ions, particularly since PFV intasomes typically generate less HSI products compared to PFV IN.

Retroviral INs have been extensively studied with biochemical assays of recombinant protein and vDNA oligomers, but fewer studies have employed intasomes. Here, we extend the biochemical characterization of PFV intasomes. PFV intasome assembly and purification was the first to be described [22]. These intasomes were visualized by crystallography and shown to include a tetramer of IN [22]. PFV intasomes readily perform integration to a plasmid target DNA in vitro [22]. We show that PFV IN appears unique among retroviral Ins in the capacity to utilize calcium as a divalent cation for strand transfer. While strand transfer activity of other retroviral Ins appears to be stimulated by Mn, PFV intasomes were inhibited by increasing concentrations of Mn [24]. The kinetics of PFV intasome product accumulation were relatively quick, with saturation occurring in $2 \mathrm{~min}$. The kinetics were not affected by the molar ratio of IN to target DNA or the addition of a small molecule that prevents PFV intasome aggregation. However, the substitution of cloride co-ions with acetate led to completion of the strand transfer reaction at $1 \mathrm{~min}$ and less accumulation of reaction products at all time points. Finally, PFV IN and intasomes do not commit to a target DNA, unlike HIV-1 IN which quickly commits to a target DNA [26]. 
In spite of structural similarities among intasomes of different retroviruses, these enzymatic properties distinguish PFV IN from other retroviral INs.

\section{Materials and Methods}

\subsection{Expression and Purification of PFV IN}

PFV IN was purified as previously described [27,28]. Briefly, hexahistidine tagged PFV IN was induced in E. coli strain BL21(DE3) pLysS with $250 \mu \mathrm{M}$ IPTG at $25^{\circ} \mathrm{C}$ for $4 \mathrm{~h}$. Soluble cellular lysate was fractionated by nickel affinity chromatography. Fractions with PFV IN were treated with HRV 3C protease to remove the hexahistidine tag. PFV IN was further purified by heparin affinity chromatography. Fractions containing highly concentrated PFV IN were combined, dialyzed against $50 \mathrm{mM}$ Tris $\mathrm{HCl}, \mathrm{pH}$ 7.5, $500 \mathrm{mM}$ $\mathrm{NaCl}, 5 \mathrm{mM}$ DTT, and 10\% glycerol, aliquoted, snap frozen with liquid nitrogen, and stored at $-80{ }^{\circ} \mathrm{C}$.

\subsection{Assembly and Purification of PFV Intasomes}

Intasomes were assembled as previously described [23]. Briefly, $50 \mathrm{mM}$ Bis-tris propane, pH 7.5, $500 \mathrm{mM} \mathrm{NaCl}, 120 \mu \mathrm{M}$ PFV IN, and $50 \mu \mathrm{M}$ vDNA were combined in a total volume of $150 \mu \mathrm{L}$ and dialyzed overnight at $18{ }^{\circ} \mathrm{C}$ against $20 \mathrm{mM}$ Bis-tris propane, $\mathrm{pH} 7.5,200 \mathrm{mM} \mathrm{NaCl}, 2 \mathrm{mM}$ DTT, and $25 \mu \mathrm{M} \mathrm{ZnCl}$. The intasome aggregates were solubilized by increasing the concentration of $\mathrm{NaCl}$ from 200 to $320 \mathrm{mM}$ and incubating on ice. The intasomes were purified by size exclusion chromatography using a Superose 12 10/300 (GE Healthcare, Chicago, IL, USA) equilibrated with 20 mM Bis-tris propane, $\mathrm{pH} 7.5,320 \mathrm{mM} \mathrm{NaCl}$, and $10 \%$ glycerol. Fractions containing intasomes were aliquoted, snap frozen with liquid nitrogen, and stored at $-80^{\circ} \mathrm{C}$. PFV intasomes appear to retain activity for one year at $-80^{\circ} \mathrm{C}$.

\subsection{Integration Assays}

Standard integration reactions were performed in $30 \mathrm{mM}$ Bis-tris propane, $\mathrm{pH} 7.5$, $110 \mathrm{mM} \mathrm{NaCl}, 5 \mathrm{mM} \mathrm{MgSO}, 4 \mu \mathrm{M} \mathrm{ZnCl}_{2}, 10 \mathrm{mM}$ DTT, indicated concentration of PFV intasomes, and $1.8 \mathrm{nM}$ supercoiled plasmid target DNA in a final volume of $15 \mu \mathrm{L}$. Reactions were incubated for $5 \mathrm{~min}$ at $37^{\circ} \mathrm{C}$, stopped with the addition of $0.5 \% \mathrm{SDS}, 0.5 \mathrm{mg} / \mathrm{mL}$ proteinase $\mathrm{K}, 25 \mathrm{mM}$ EDTA ( $\mathrm{pH} 8.0$ ), and incubated for $1 \mathrm{~h}$ at $37^{\circ} \mathrm{C}$. Integration products were resolved with $1.25 \%$ agarose gel electrophoresis. Gels were stained with ethidium bromide and imaged for ethidium bromide and Cy5 fluorescence (Sapphire Biomolecular Imager, Azure Biosystems, Dublin, CA, USA). Cy5 fluorescence was quantified using AzureSpot gel analysis software (Azure Biosystems, Dublin, CA, USA). Where indicated, $5 \mathrm{mM}$ PCA was included in reactions. Acetate buffer included $25 \mathrm{mM}$ Tris- $\mathrm{HCl}, \mathrm{pH} 7.4$, $125 \mathrm{mM} \mathrm{NaOAc}, 5 \mathrm{mM} \mathrm{MgOAc}, 10 \mu \mathrm{M} \mathrm{ZnCl}, 1 \mathrm{mM}$ DTT. In assays comparing buffers, $20 \mathrm{nM}$ PFV intasome was added to reaction buffer and incubated on ice for indicated times before addition of $1.8 \mathrm{nM} 3 \mathrm{~kb}$ supercoiled pGEMT plasmid. At the addition of target DNA, reactions were incubated at $37^{\circ} \mathrm{C}$ for $5 \mathrm{~min}$ and analyzed as standard integration reactions. $p$ values were determined by two tail paired $t$ test. Error bars indicate standard deviation between at least three independent experiments performed with at least two independent intasome preparations.

\section{Results}

\subsection{PFV Intasome Requirements for Divalent Cations}

Retroviral intasomes may be assembled with a preprocessed vDNA and purified recombinant PFV IN [22]. The vDNA may be labeled with a fluorophore, such as Cy5, to identify integration products by fluorescence imaging [23]. The assembled complexes are purified by size exclusion chromatography. To assay integration activity, the PFV intasomes are diluted in a buffer containing a divalent cation and target DNA. Addition of supercoiled plasmid as the target DNA allows facile visualization and quantitation of the integration products. Concerted integration $\left(\mathrm{CI}_{1}\right)$ of both vDNAs to a circular plasmid yields a linear 
product with vDNA at the ends (Figure 1). Additional $\mathrm{CI}\left(\mathrm{CI}_{2}\right)$ to the linear product results in fragments shorter than the linear product. Half site integration (HSI) is the joining of a single vDNA to the plasmid and results in a fluorescently tagged plasmid with the mobility of a relaxed circle. Autointegration (AI) products result from integration of one vDNA to another vDNA and have slightly slower mobility compared to unreacted vDNA. These reaction products are resolved by agarose gel electrophoresis. The agarose gel is imaged for ethidium bromide and $\mathrm{Cy} 5$ fluorescence and quantified. Integration products are distinguished by their mobilities and presence of the fluorophore.

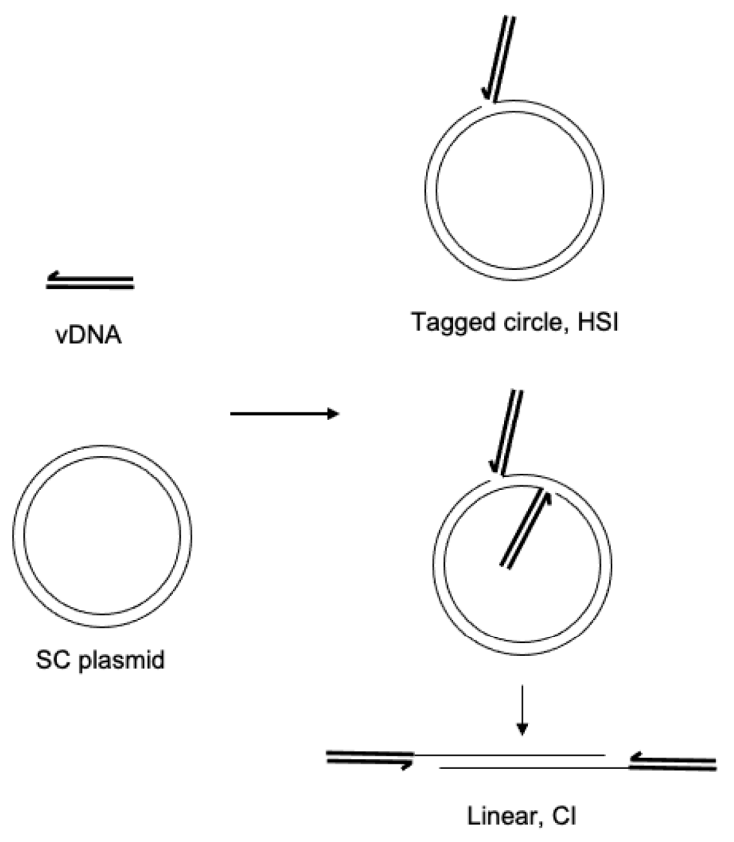

Figure 1. Integration assay reaction products. DNA oligomers mimicking the viral cDNA ends (vDNA, heavy black lines) are assembled with PFV IN to form intasomes. The intasomes are added to a supercoiled plasmid (SC plasmid, light black lines) and incubated at $37^{\circ} \mathrm{C}$. The major products of integration are concerted integration (CI) where the two vDNAs of the intasome are covalently joined to the target SC plasmid. This results in a linear product with the vDNAs at each end. Additional CI to the linear product will result in shorter fragments. A minor product of intasome integration is half site integration (HSI), where only one vDNA is joined to the target DNA resulting in a tagged circle.

PFV intasomes with preprocessed vDNA were assembled without a divalent metal ion. The intasomes were purified by size exclusion chromatography in the continued absence of a divalent metal ion, indicating that the complexes are stable without cations. The use of a preprocessed vDNA allows analysis of strand transfer activity. PFV integration assays are commonly performed in the presence of magnesium sulfate [25,29]. PFV intasome integration to a supercoiled plasmid was performed with a titration of magnesium sulfate (Figure 2A). In the absence of cation, PFV intasomes are unable to perform strand transfer. Maximal concerted integration activity was observed in the presence of $5 \mathrm{mM}$ magnesium sulfate. Similar results were seen with a titration of magnesium chloride (Figure 2B). There was no statistically significant difference between PFV integration activity in the presence of magnesium sulfate or magnesium chloride ( $p>0.05$ at all equivalent concentrations). 
A
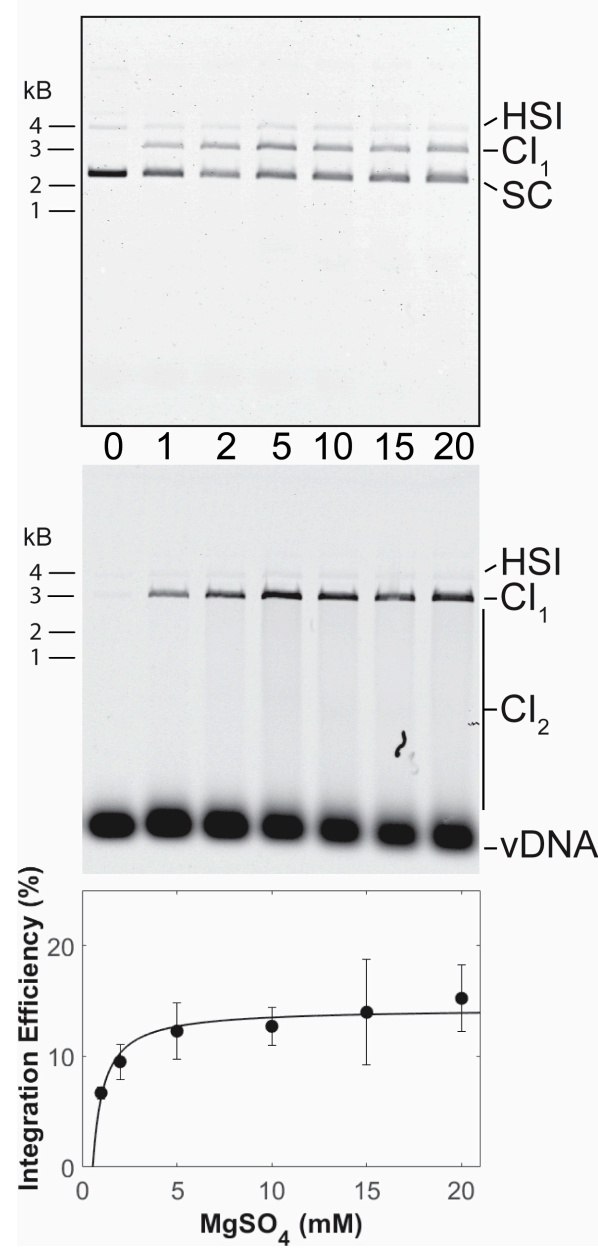

B

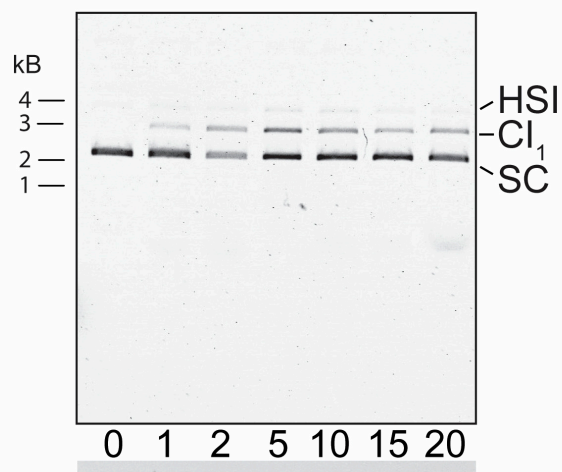

$\mathrm{kB}-\mathrm{HSI}$

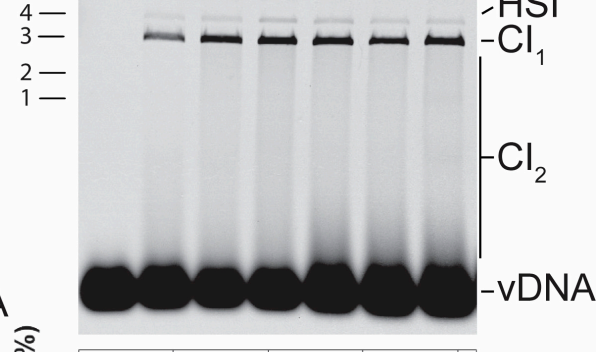

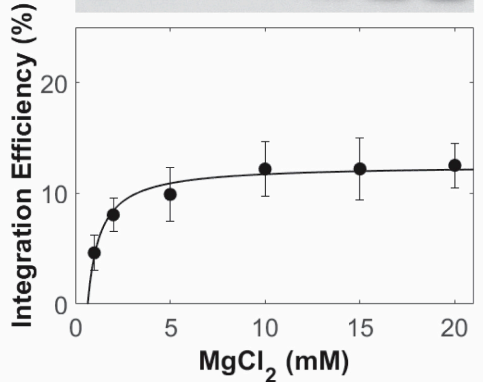

Figure 2. PFV intasome integration in the presence of $\mathrm{Mg}$. Integration activity was assayed with a titration of $(\mathbf{A}) \mathrm{MgSO}_{4}$ or $(\mathbf{B}) \mathrm{MgCl}_{2}$. Reaction products were resolved by agarose gel electrophoresis. The gel was imaged for ethidium bromide (top) and Cy5 (center) fluorescence. Half site integration (HSI), the first concerted integration product $\left(\mathrm{CI}_{1}\right)$, and subsequent concerted integration products $\left(\mathrm{CI}_{2}\right)$ are shown. Unreacted supercoiled plasmid target DNA (SC) is visible on in the ethidium bromide image. Unreacted vDNA is only visible in the Cy5 image. The total Cy 5 fluorescence in each lane was quantified and each integration product calculated as the fraction of the total fluorescence (bottom). The average of three independent experiments with at least two independent intasomes preparations is shown. Error bars indicate the standard deviation.

PFV intasomes were also assayed for integration activity in manganese chloride and calcium chloride. Intasomes were most active in the presence of $1 \mathrm{mM}$ manganese chloride (Figure 3). In contrast to magnesium, increasing the concentration of manganese chloride led to decreased integration activity. Previous studies of HIV-1 IN also revealed an inhibition of strand transfer, but only at $64 \mathrm{mM}$ manganese chloride [30]. PFV intasomes were also assayed with a titration of calcium chloride (Figure 4). Many retroviral integrases are not active in the presence of calcium. However, PFV intasomes were active in the presence of calcium chloride and activity increased with increasing concentrations of calcium chloride. In the presence of this divalent metal cation, integration products were mostly HSI. Employing a higher concentration of PFV intasomes revealed the formation of $\mathrm{CI}$ products in the presence of $\mathrm{Ca}$. These data highlight the unique characteristics of PFV IN divalent metal requirements compared to other retroviral INs. 


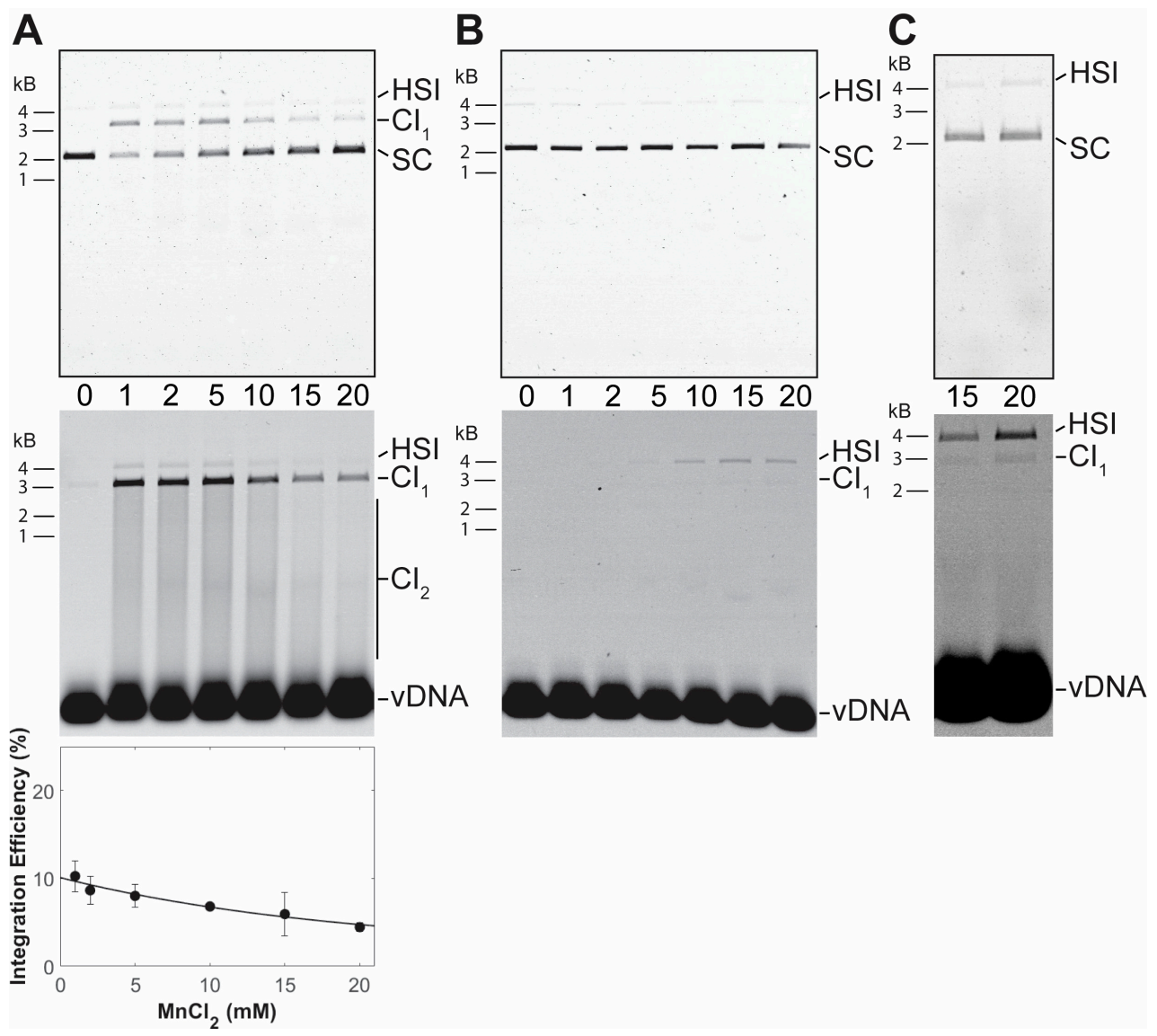

Figure 3. PFV intasome integration in the presence of $\mathrm{MnCl}_{2}$ or $\mathrm{CaCl}_{2}$. (A) Integration activity was assayed with a titration of $\mathrm{MnCl}_{2}$ and $10 \mathrm{nM} \mathrm{PFV}$ intasomes. Reaction products were resolved by agarose gel electrophoresis. The gel was imaged for ethidium bromide (top) and Cy5 (center) fluorescence. Half site integration (HSI), the first concerted integration product $\left(\mathrm{CI}_{1}\right)$, and subsequent concerted integration products $\left(\mathrm{CI}_{2}\right)$ are shown. Unreacted supercoiled plasmid target DNA (SC) is visible on in the ethidium bromide image. Unreacted vDNA is only visible in the Cy5 image. The total Cy5 fluorescence in each lane was quantified and each integration product calculated as the fraction of the total fluorescence (bottom). The average of three independent experiments with at least two independent intasomes preparations is shown. Error bars indicate the standard deviation. (B) $10 \mathrm{nM}$ PFV intasomes were assayed for integration with a titration of $\mathrm{CaCl}_{2}$. Reaction products were resolved by agarose gel electrophoresis. The gel was imaged for ethidium bromide (top) and $\mathrm{Cy} 5$ (center) fluorescence. HSI and $\mathrm{CI}_{1}$ are shown. Unreacted SC target DNA is visible on in the ethidium bromide image. Unreacted vDNA is only visible in the Cy5 image. The reaction products were $<1 \%$ of the fluorescent signal in each lane and could not be accurately quantified. (C) A higher concentration of PFV intasomes, $45 \mathrm{nM}$, was assayed to confirm the presence of CI products in the presence of $\mathrm{Ca}$.

\subsection{PFV Intasome Mediated Integration Is Quick}

PFV intasomes were previously shown to complete integration within 5 min at $37^{\circ} \mathrm{C}$ with either a supercoiled plasmid target or a nucleosome target [31,32]. However, there was only one earlier time point assayed in those studies. For a more accurate determination of intasome kinetics, we extended the time course with the same buffer conditions and found that integration is complete within $2 \mathrm{~min}$ at $37^{\circ} \mathrm{C}$ (Figure 4 ). 

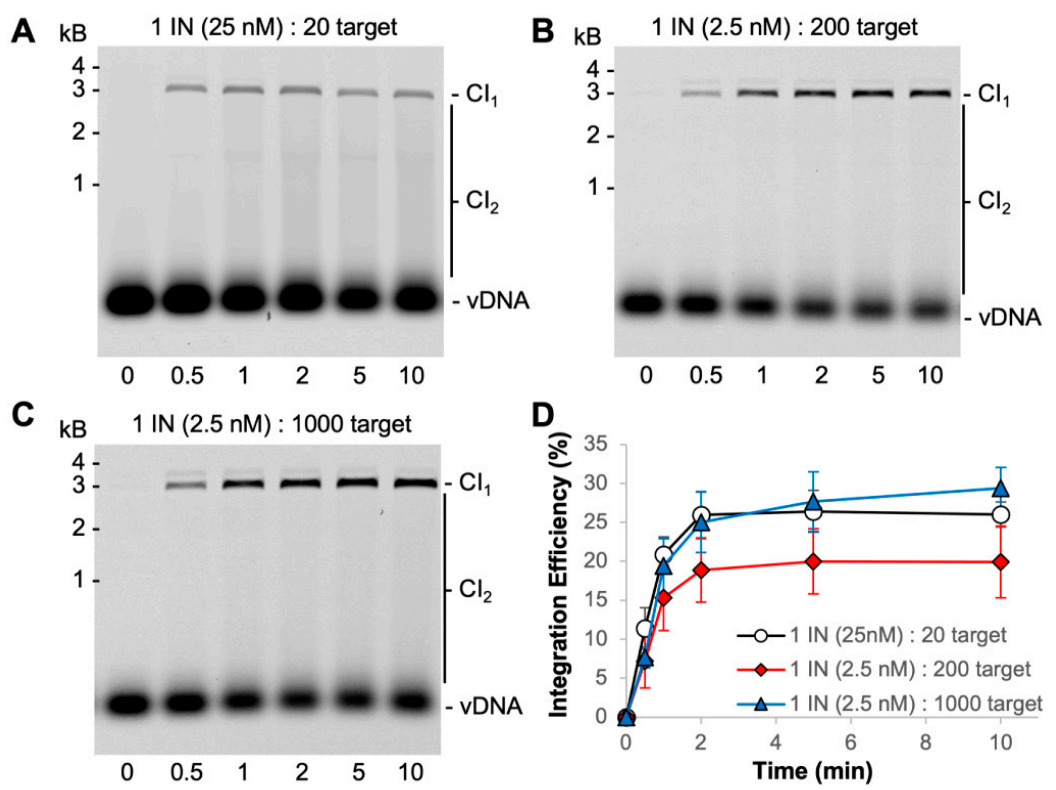

Figure 4. Increasing the molar ratio of target to PFV intasomes. (A) Typical reaction conditions with 25 nM PFV intasomes are 20-fold molar excess of target sites to intasomes; (B) reducing the intasome concentration to $2.5 \mathrm{nM}$ increases the molar excess of target sites to 200-fold; (C) increasing the target DNA concentration allowed for 1000-fold molar excess of target sites to $2.5 \mathrm{nM}$ intasomes. Cy5 images of agarose gels show the accumulation of $\mathrm{CI}_{1}$ and $\mathrm{CI}_{2}$ products over time. (D) The total Cy5 fluorescence in each lane was quantified and each integration product calculated as the fraction of the total fluorescence. The average of three independent experiments with at least two independent intasomes preparations is shown. Error bars indicate the standard deviation.

The PFV intasome footprint appears to be $\sim 10 \mathrm{bp}$ of target DNA [33]. A $3000 \mathrm{bp}$ plasmid target offers 300 possible integration sites. Integration assays were performed with a molar excess of target sites to PFV intasomes (Figure 4) [31,34]. Reactions with $25 \mathrm{nM}$ PFV intasomes are at a 20 -fold molar excess of target sites to intasomes. The intasome concentration was reduced to $2.5 \mathrm{nM}$ in order to evaluate a 200 -fold molar excess of target sites. The 200-fold molar excess reactions yielded less CI products, particularly $\mathrm{CI}_{2}$ products, compared to 20 -fold molar excess of target sites. All reactions were complete by $2 \mathrm{~min}$. The amount of target plasmid included in the reactions was increased to obtain a 1000 -fold molar excess of target sites to $2.5 \mathrm{nM}$ intasomes. The data with altered molar ratios of target substrate to intasomes consistently show the reaction to be complete at $2 \mathrm{~min}$. Neither the substrates nor the intasomes were completely consumed during these reactions.

The short reaction time of PFV intasome-mediated integration makes classic MichaelisMenten analysis of enzyme kinetics difficult. Previous studies showed that PFV intasomes incubated at $37^{\circ} \mathrm{C}$ for $5 \mathrm{~min}$ before the addition of target lost integration activity [31]. However, addition of the small molecule PCA significantly rescued the activity of the preincubated PFV intasomes. This was attributed, at least in part, to the ability of PCA to prevent aggregation of PFV intasomes at physiologically relevant ionic strength buffer conditions [31]. PCA was added to PFV intasomes to test the ability of this small molecule to lengthen the time that intasomes are active beyond $2 \mathrm{~min}$ (Figure 5). Two PFV intasome concentrations were assayed in the presence or absence of PCA. The presence of PCA had no effect on the accumulation of CI products over time and reaction products saturated by $2 \mathrm{~min}$. These data suggest that while PCA prevents the aggregation of PFV intasomes, the completion of integration at $2 \mathrm{~min}$ was not due to aggregation of complexes. 

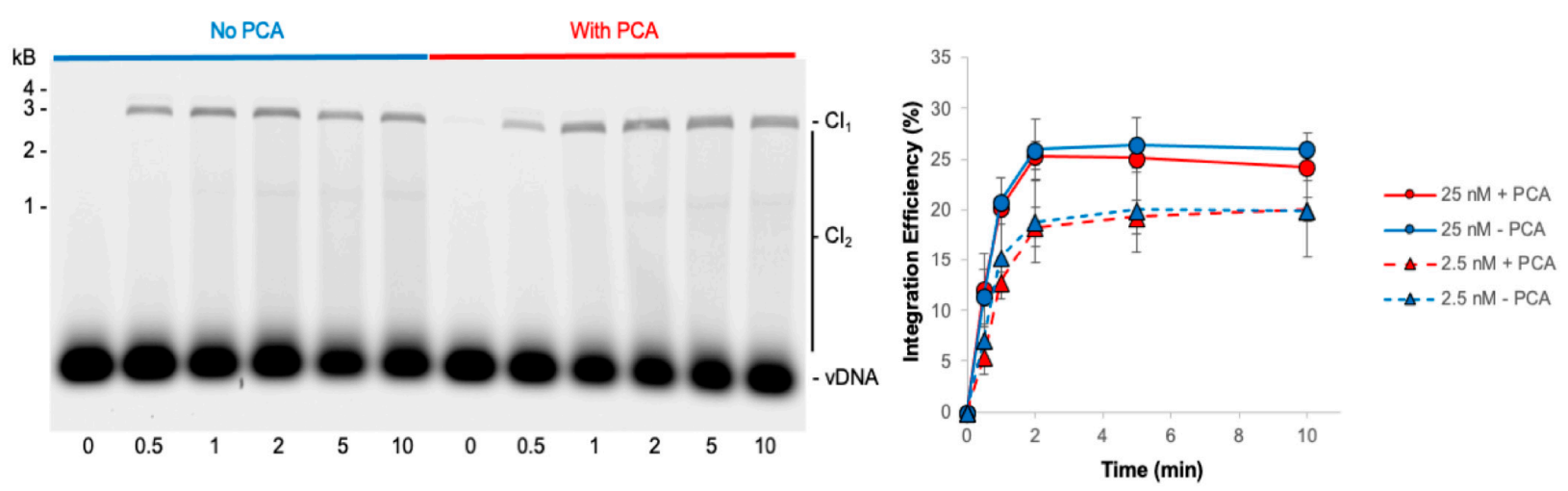

Figure 5. PCA does not alter the kinetics of PFV intasome integration. PFV integration over time was assayed in the absence or presence of $5 \mathrm{mM}$ PCA. As PCA has been shown to reduce aggregation of PFV intasomes, two concentrations of intasomes were assayed: 25 and $2.5 \mathrm{nM}$. Cy5 image of agarose gel with $25 \mathrm{nM}$ PFV intasomes shows the accumulation of $\mathrm{CI}_{1}$ and $\mathrm{CI}_{2}$ products over time. The total $\mathrm{Cy} 5$ fluorescence in each lane was quantified and each integration product calculated as the fraction of the total fluorescence. PCA did not affect the kinetics of integration at either concentration. The average of three independent experiments with at least two independent intasomes preparations is shown. Error bars indicate the standard deviation.

\subsection{PFV Intasomes Are Less Active in the Presence of Acetate Buffer}

Studies of PFV intasome activity are routinely performed in the presence of $\mathrm{NaCl}$ and $\mathrm{MgCl}_{2}$ or $\mathrm{MgSO}_{4}[25,29,31,34-41]$. PFV IN strand transfer showed no difference in the presence of $\mathrm{MgSO}_{4}$ or $\mathrm{MgCl}_{2}$ indicating no significant effects of sulfite or chloride co-ions (Figure 2) [25]. A recent study employed sodium acetate (NaOAc) and magnesium acetate (MgOAc) during assays of PFV intasome activities [42]. This led to results contradicting previously published results obtained with buffer containing $\mathrm{NaCl}$ and $\mathrm{MgSO}_{4}$ [34]. While Jones et al. were able to measure the time between PFV concerted strand transfer events by magnetic tweezers in the presence of $\mathrm{NaCl}$ and $\mathrm{MgSO}_{4}$, Vanderlinden et al. were only able to observe HSI in the presence of $\mathrm{NaOAc}$ and MgOAc. To address the difference in experimental outcomes, PFV intasome activity was directly compared in the presence of a buffer with $\mathrm{NaOAc}$ and $\mathrm{MgOAc}$ to a buffer containing $\mathrm{NaCl}$ and $\mathrm{MgSO}_{4}$.

PFV intasome integration activity was measured over time in two different buffer conditions (Figure 6A). PFV intasomes were active in both buffers generating readily visualized $\mathrm{CI}$ products. However, the intasomes displayed more $\mathrm{CI}$ in buffer with $\mathrm{NaCl}$ and $\mathrm{MgSO}_{4}$. The relative increase in $\mathrm{CI}$ product accumulation in the presence of $\mathrm{NaCl}$ and $\mathrm{MgSO}_{4}$ is apparent at $0.5 \mathrm{~min}$. In addition, accumulation of $\mathrm{CI}$ products plateaus in the presence of $\mathrm{NaCl}$ and $\mathrm{MgSO}_{4}$ at 2 min incubation. However, $\mathrm{CI}$ is complete at $1 \mathrm{~min}$ in the acetate buffer. These data indicate that PFV intasomes are less active in acetate buffers.

The quick reaction kinetics of PFV intasomes suggested that practical considerations may also play a role in integration assays. In the case of single-molecule magnetic tweezer assays, PFV intasomes are typically diluted in reaction buffer before loading to a flow cell. In some cases, the diluted intasomes may remain on ice before being exposed to target DNA within the flow cell. The two different reaction buffers were tested for their effects on intasomes incubated on ice (Figure 6B). PFV intasomes were diluted to a working concentration in reaction buffer and incubated on ice for a variable time. Following variable incubation time on ice, target DNA was added and the reactions were immediately transferred to $37^{\circ} \mathrm{C}$ for $5 \mathrm{~min}$. PFV intasome incubation on ice led to reduced activity over time in both buffers. However, the intasomes in acetate buffer lost $50 \%$ of their integration activity after $30 \mathrm{~min}$ and $55 \%$ after $60 \mathrm{~min}$ on ice. Intasomes in buffer with $\mathrm{NaCl}$ and $\mathrm{MgSO}_{4}$ lost $37 \%$ of their activity after $30 \mathrm{~min}$ and $42 \%$ after $60 \mathrm{~min}$ of incubation on ice. These data indicate that PFV intasomes are more prone to loss of activity in acetate buffer compared to buffer with $\mathrm{NaCl}$ and $\mathrm{MgSO}_{4}$. 

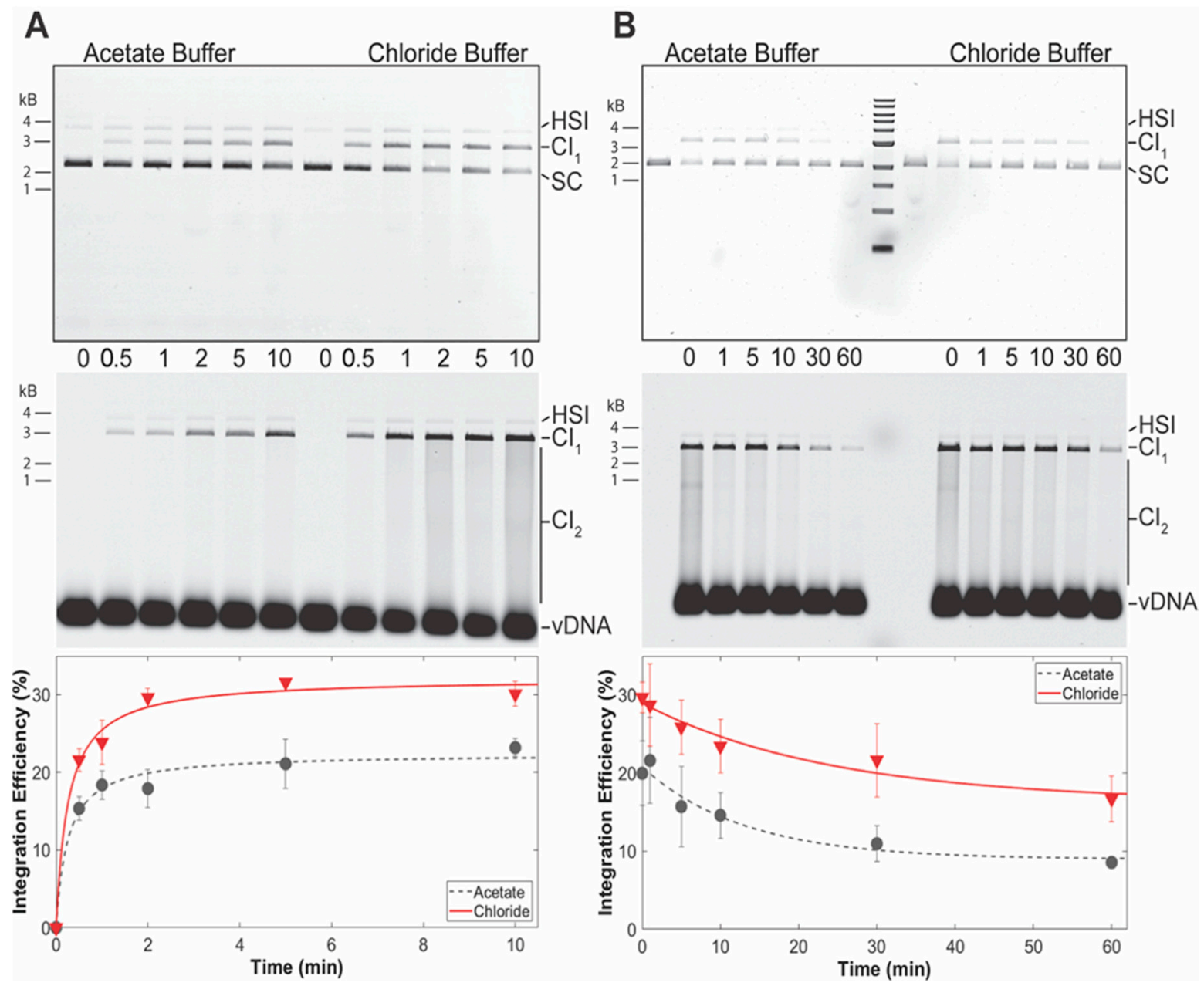

Figure 6. PFV intasomes are more active in chloride buffers. (A) PFV integration over time was assayed in the presence of standard chloride buffer or an acetate buffer; (B) PFV intasomes were diluted in chloride or acetate buffer and kept on ice for variable time before the addition of target DNA and immediate transfer to $37^{\circ} \mathrm{C}$. Reaction products were resolved by agarose gel electrophoresis. The gel was imaged for ethidium bromide (top) and Cy5 (center) fluorescence. Half site integration (HSI), the first concerted integration product $\left(\mathrm{CI}_{1}\right)$, and subsequent concerted integration products $\left(\mathrm{CI}_{2}\right)$ are shown. Unreacted supercoiled plasmid target DNA (SC) is visible on in the ethidium bromide image. Unreacted vDNA is only visible in the Cy5 image. The total Cy5 fluorescence in each lane was quantified and each integration product calculated as the fraction of the total fluorescence (bottom). The average of three independent experiments with at least two independent intasomes preparations is shown. Error bars indicate the standard deviation.

\subsection{PFV Intasomes Do Not Commit to Target DNA}

HIV-1 IN was previously shown to quickly commit to a target DNA [26]. In these assays, HIV-1 IN and vDNA were added to a plasmid and incubated at $37^{\circ} \mathrm{C}$. At variable times a second plasmid of differing size was added to the reaction. HIV-1 IN performed equivalent integration to both plasmids when they were added simultaneously. However, HIV-1 IN appeared to fully commit to the first plasmid within $20 \mathrm{~s}$ with no integration to a second plasmid. In contrast, similar experiments showed that PFV IN integrated to a second plasmid up to $60 \mathrm{~min}$ after the addition of the first plasmid [25]. Both of these experimental approaches employed free IN and vDNA rather than assembled intasomes.

We tested the commitment of PFV intasomes to two plasmid DNA targets, $3 \mathrm{~kb}$ and $6 \mathrm{~kb}$ (Figure 7). Reactions were performed with $2.5 \mathrm{nM}$ PFV intasomes to reduce the amount of $\mathrm{CI}_{2}$ products which would confound quantitation. When the plasmids were added to the reaction simultaneously, integration to the plasmids was equivalent. As seen with a single plasmid target, integration was complete by $2 \mathrm{~min}$. At times shorter than $2 \mathrm{~min}$, PFV 
intasomes integrated to either plasmid. Over time, the fraction of integration to the first plasmid increased and integration to the second plasmid decreased. For the entire time that PFV intasomes are active, they are able to integrate to either plasmid. The integration dynamics were unaffected by whether the smaller or larger plasmid was added first. These results suggest that PFV intasomes do not fully commit to a target DNA early, as seen with free HIV-1 IN.
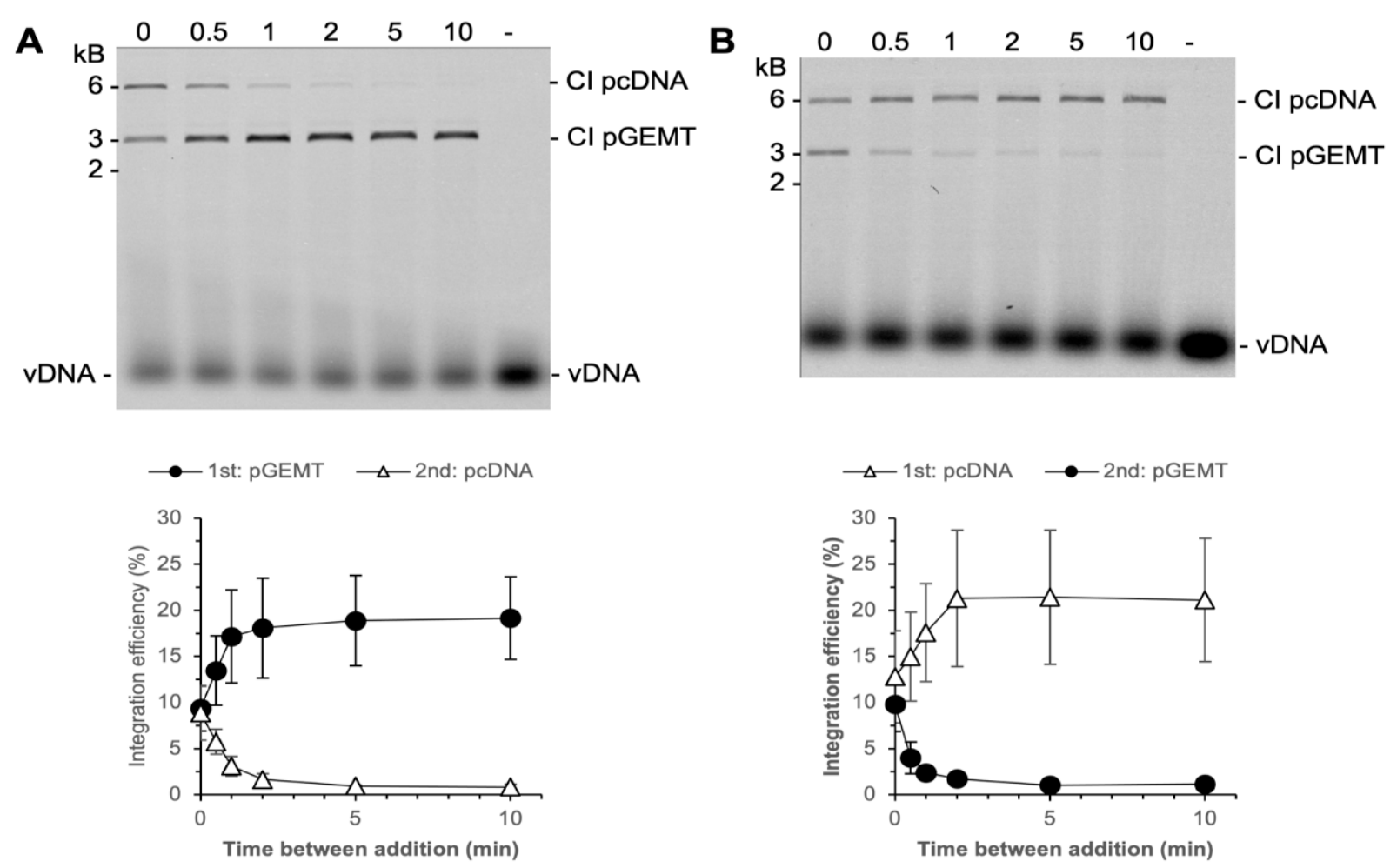

Figure 7. PFV intasomes do not commit early to target DNA. Integration reactions were performed with a $3 \mathrm{~kb}$ and a $6 \mathrm{~kb}$ plasmid. Reactions were started with one plasmid and a second plasmid added at variable time later. The zero time point represents plasmids added simultaneously to the reaction. (A) The $3 \mathrm{~kb}$ plasmid was added first and the $6 \mathrm{~kb}$ plasmid added second; (B) the $6 \mathrm{~kb}$ plasmid was added first and the $3 \mathrm{~kb}$ plasmid was added second. The total Cy5 fluorescence in each lane was quantified and each integration product calculated as the fraction of the total fluorescence (bottom). The average of three independent experiments with at least two independent intasomes preparations is shown. Error bars indicate the standard deviation.

\section{Discussion}

Many enzymes that utilize two divalent metal cations for catalysis display activity in $\mathrm{Mg}$ or Mn, but not Ca. It has been noted that obvious factors such as the different sizes of the ions or coordination number do not correlate well with the observed differences of enzymatic activity [14]. The mechanism of cation preference is not clear, but several hypotheses have been proposed. The reaction energy barrier in the presence of $\mathrm{Ca}$ appears to be raised for both RNaseH and BamHI [9,14]. Another factor may be the larger atomic radius of $\mathrm{Ca}$ compared to $\mathrm{Mg}$ [10]. Observations of $\mathrm{RNaseH}$ suggested that the architecture of the active site was the same in the presence of $\mathrm{Ca}$ or $\mathrm{Mg}$, but changes in ion coordination geometry were observed [9]. This may be a key factor considering the structural similarities of retroviral intasomes at the active site in what has been termed a conserved intasome core (CIC) [43]. Structural studies of PFV intasomes in the presence of Mg or Mn described the octahedral coordination for both binding sites, but Ca was not included in the analysis [44] Instead of a single difference between cations defining catalytic function, a combination of features may account for the ability—or not—of an enzyme to function in the presence of Ca [15]. 
It is unclear why PFV IN, of all retroviral INs, appears uniquely able to utilize Ca in strand transfer catalysis. HIV-1 IN has been the most widely studied for its activity in the presence of various divalent cations [45]. Divalent metals were shown to be required for assembly of the integration complex, $3^{\prime}$ end processing, and strand transfer. HIV-1 IN was shown to efficiently use $\mathrm{Mg}$ or Mn for all three activities [19,30]. However, HIV-1 IN could only use Ca for assembly, not $3^{\prime}$ processing or strand transfer [19]. It could use Co for strand transfer, but not assembly or $3^{\prime}$ processing [19]. Similarly, ASV IN performs strand transfer in the presence of $\mathrm{Mg}$ or $\mathrm{Mn}$, with better efficiency in the latter [24]. HIV-1 preintegration complexes (PICs) derived from cells and recombinant MMTV intasomes are inactive in the presence of $\mathrm{Ca}$ [46-48]. MMTV intasomes display greater strand transfer activity in Mn compared to $\mathrm{Mg}$ at concentrations $\leq 10 \mathrm{mM}$, but also perform more AI in $\mathrm{Mn}$ at these concentrations, suggesting a lack of specificity [48]. PFV intasomes do not require any divalent cation for assembly $[22,33]$. By comparing integration with blunt or preprocessed vDNA, PFV IN was shown to use $\mathrm{Mg}$ or Mn for $3^{\prime}$ processing, but not $\mathrm{Ca}$ [25]. These experiments also revealed that PFV IN can use Ca for strand transfer (Figure 5) [25]. In addition to the difference in ability to perform strand transfer in the presence of $\mathrm{Ca}$, PFV intasomes also differed from other retroviral INs and intasomes by their activity in Mn. Retroviral INs have been reported to have equal activity in $\mathrm{Mg}$ and $\mathrm{Mn}$ or better activity in Mn $[19,24,30]$. HIV-1 IN was shown to be inhibited at $>32 \mathrm{mM}$ Mn [30]. MMTV intasome strand transfer activity correlated with increased Mn concentrations up to $15 \mathrm{mM}$ [48]. In contrast, PFV intasome strand transfer activity displays an inverse correlation with $\mathrm{Mn}$ concentration (Figure 5).

Multiple transposases have also been characterized for their ability to utilize different divalent cations. Similar to INs, transposases assemble complexes and perform the same single-step transesterification reactions. Phage Mu transposase MuA forms a tetramer and can also perform strand transfer in the presence of $\mathrm{Ca}$ [11]. MuA must cleave the Mu DNA ends to form a cleaved donor complex, but is not able to utilize Ca for this activity [11]. This is not true for all transposases, as Tn10 transposase has no activity in the presence of $\mathrm{Ca}$ [12]. Thus, PFV IN activities in the presence of $\mathrm{Ca}$ are more similar to MuA transposase than to other retroviral Ins or transposases.

In addition to divalent metal cations, retroviral INs require sodium $(\mathrm{Na})$ or potassium (K) cations. PFV intasomes were previously characterized for their strand transfer activity in a titration of $\mathrm{NaCl}$ [32]. Analysis of integration to alternative target DNAs revealed maximal strand transfer activity at variable $\mathrm{NaCl}$ concentrations. Integration to a supercoiled plasmid was maximal at $200 \mathrm{mM} \mathrm{NaCl}$ and to a mononucleosome at $150 \mathrm{mM} \mathrm{NaCl}$ [32]. The kinetics of PFV or MMTV intasome integration to plasmid or nucleosome DNA were shown to be the same [32,48]. These data suggest that the observations of intasome integration to plasmid DNA will be indicative of integration to more physiologically relevant nucleosome targets.

The use of co-ion by retroviral INs has not been thoroughly studied. The divalent metal cation is necessary for IN catalysis, but the role of the co-ion during a reaction is unclear. Interestingly, the presence of OAc co-ions results in less strand transfer activity of PFV intasomes compared to $\mathrm{Cl}$ co-ions. The OAc co-ion also led to earlier saturation of reaction products. These results suggest that PFV intasomes are more active in the presence of $\mathrm{Cl}$ co-ions. Future studies of retroviral intasomes should consider co-ion effects on enzymatic activity.

PFV IN also appears to be distinguishable from HIV-1 IN by a lack of commitment to a target DNA. HIV-1 IN and gel-filtered HIV-1 PICs derived from infected cells were previously shown to commit to a target DNA within $20 \mathrm{~s}$ [26]. Interestingly, addition of a cellular extract to gel-filtered HIV-1 PICs allowed integration to a second target [26]. It is unknown what cellular factor might allow HIV-1 PICs to display reduced target commitment. It is possible that the known host co-factor for HIV-1 integration lens epithelium-derived growth factor $75 \mathrm{kD}$ splice variant (LEDGF)/p75 was removed from PICs during gel filtration. In stark contrast to the early target commitment of HIV-1 IN, PFV IN was previously 
shown to efficiently integrate to a second target DNA during a 60 min reaction [25]. Here we observed that PFV intasomes are also able to integrate to a second target DNA at any time while they are active (Figure 7). It should be noted that PFV intasomes do not have a known host co-factor. The lack of PFV IN or PFV intasome early target commitment could be due to 3D searching of target DNAs or relatively slow binding followed by fast reaction kinetics. These experiments did not distinguish these two models. A combination of 1D and 3D searching of DNA can enhance the ability of an enzyme to identify a target site [49]. Regardless of the mechanism, the PFV IN promiscuous interaction with target DNA is demonstrably different from the observed HIV-1 IN or gel-filtered HIV-1 PIC fast commitment to target DNA. HIV-1 PICs may require a host co-factor to allow 3D searching and a more efficient search for a preferred integration site.

These results highlight the unique biochemical characteristics of PFV IN compared to other retroviral INs. All retroviruses display unique patterns of integration to the genome during infection [50]. PFV displays minimal preferences for genomic elements, such as transcription start sites and cytosine guanine (CpG) islands [51]. Most retroviral integration is directed by a host integration co-factor, such as LEDGF/p75 for HIV-1 integration [52,53]. However, PFV integration appears to be targeted by the viral Gag protein [51]. Thus, PFV integration in cells differs from other retroviruses by the use of a viral protein to tether the integration complex to chromatin, rather than a host protein. Indeed, the foamy viruses are non-pathogenic and exhibit a life cycle unique among retroviruses [54]. These results extend those observations by showing that PFV intasomes also display unique biochemical characteristics. Our data suggests that retroviral intasomes display variable activity depending on the buffer conditions, which may not be predictable despite the structural similarities at the IN active site observed in multiple retroviral intasome structures [20-22,33,55-57]. Further biochemical studies of additional retroviral intasomes will reveal their unique properties.

Author Contributions: Conceptualization, K.E.Y.; methodology, A.J.R. and Y.Y.T.; formal analysis, A.J.R. and Y.Y.T.; writing—original draft preparation, A.J.R., Y.Y.T. and K.E.Y.; writing—review and editing, A.J.R., Y.Y.T., R.C.L. and K.E.Y.; supervision, R.C.L. and K.E.Y.; funding acquisition, K.E.Y. All authors have read and agreed to the published version of the manuscript.

Funding: This research was funded by NIH NIAID AI126742.

Institutional Review Board Statement: Not applicable.

Informed Consent Statement: Not applicable.

Data Availability Statement: All relevant data to this study are presented. Additional data may be provided upon request.

Conflicts of Interest: The authors declare no conflict of interest.

\section{References}

1. Coffin, J.M.; Hughes, S.H.; Varmus, H.E. Retroviruses; Cold Spring Harbor Laboratory Press: Cold Spring Harbor, NY, USA, 1997.

2. Yoder, K.E.; Bushman, F.D. Repair of gaps in retroviral DNA integration intermediates. J. Virol. 2000, 74, 11191-11200. [CrossRef] [PubMed]

3. Varadarajan, J.; McWilliams, M.J.; Hughes, S.H. Treatment with suboptimal doses of raltegravir leads to aberrant HIV-1 integrations. Proc. Natl. Acad. Sci. USA 2013, 110, 14747-14752. [CrossRef]

4. Varadarajan, J.; McWilliams, M.J.; Mott, B.T.; Thomas, C.J.; Smith, S.J.; Hughes, S.H. Drug resistant integrase mutants cause aberrant HIV integrations. Retrovirology 2016, 13, 71. [CrossRef] [PubMed]

5. Craigie, R. HIV integrase, a brief overview from chemistry to therapeutics. J. Biol. Chem. 2001, 276, 23213-23216. [CrossRef]

6. Engelman, A.; Cherepanov, P. Retroviral Integrase Structure and DNA Recombination Mechanism. Microbiol. Spectr. 2014, 2, 1-22. [CrossRef]

7. Engelman, A.; Mizuuchi, K.; Craigie, R. HIV-1 DNA integration: Mechanism of viral DNA cleavage and DNA strand transfer. Cell 1991, 67, 1211-1221. [CrossRef]

8. Ellison, V.; Gerton, J.; Vincent, K.A.; Brown, P.O. An essential interaction between distinct domains of HIV-1 integrase mediates assembly of the active multimer. J. Biol. Chem. 1995, 270, 3320-3326. [CrossRef] [PubMed] 
9. Rosta, E.; Yang, W.; Hummer, G. Calcium inhibition of ribonuclease H1 two-metal ion catalysis. J. Am. Chem. Soc. 2014, 136, 3137-3144. [CrossRef] [PubMed]

10. Zhao, H.; Lin, Z.; Lynn, A.Y.; Varnado, B.; Beutler, J.A.; Murelli, R.P.; Le Grice, S.F.; Tang, L. Two distinct modes of metal ion binding in the nuclease active site of a viral DNA-packaging terminase: Insight into the two-metal-ion catalytic mechanism. Nucleic Acids Res. 2015, 43, 11003-11016. [CrossRef] [PubMed]

11. Savilahti, H.; Rice, P.A.; Mizuuchi, K. The phage Mu transpososome core: DNA requirements for assembly and function. EMBO J. 1995, 14, 4893-4903. [CrossRef] [PubMed]

12. Junop, M.S.; Haniford, D.B. Multiple roles for divalent metal ions in DNA transposition: Distinct stages of Tn10 transposition have different $\mathrm{Mg} 2+$ requirements. EMBO J. 1996, 15, 2547-2555. [CrossRef]

13. Deweese, J.E.; Osheroff, N. The use of divalent metal ions by type II topoisomerases. Metallomics 2010, 2, 450-459. [CrossRef]

14. Mordasini, T.; Curioni, A.; Andreoni, W. Why do divalent metal ions eiTher. promote or inhibit enzymatic reactions? The case of BamHI restriction endonuclease from combined quantum-classical simulations. J. Biol. Chem. 2003, 278, 4381-4384. [CrossRef]

15. Nowotny, M.; Yang, W. Stepwise analyses of metal ions in RNase H catalysis from substrate destabilization to product release. EMBO J. 2006, 25, 1924-1933. [CrossRef]

16. Leschziner, A.E.; Griffin IV, T.J.; Grindley, N.D. Tn552 transposase catalyzes concerted strand transfer in vitro. Proc. Natl. Acad. Sci. USA 1998, 95, 7345-7350. [CrossRef]

17. Sissi, C.; Palumbo, M. Effects of magnesium and related divalent metal ions in topoisomerase structure and function. Nucleic Acids Res. 2009, 37, 702-711. [CrossRef]

18. Junop, M.S.; Haniford, D.B. Factors responsible for target site selection in Tn10 transposition: A role for the DDE motif in target DNA capture. EMBO J. 1997, 16, 2646-2655. [CrossRef]

19. Hazuda, D.J.; Felock, P.J.; Hastings, J.C.; Pramanik, B.; Wolfe, A.L. Differential divalent cation requirements uncouple the assembly and catalytic reactions of human immunodeficiency virus type 1 integrase. J. Virol. 1997, 71, 7005-7011. [CrossRef] [PubMed]

20. Ballandras-Colas, A.; Brown, M.; Cook, N.J.; Dewdney, T.G.; Demeler, B.; Cherepanov, P.; Lyumkis, D.; Engelman, A.N. Cryo-EM reveals a novel octameric integrase structure for betaretroviral intasome function. Nature 2016, 530, 358-361. [CrossRef] [PubMed]

21. Ballandras-Colas, A.; Maskell, D.P.; Serrao, E.; Locke, J.; Swuec, P.; Jonsson, S.R.; Kotecha, A.; Cook, N.J.; Pye, V.E.; Taylor, I.A.; et al. A supramolecular assembly mediates lentiviral DNA integration. Science 2017, 355, 93-95. [CrossRef] [PubMed]

22. Hare, S.; Gupta, S.S.; Valkov, E.; Engelman, A.; Cherepanov, P. Retroviral intasome assembly and inhibition of DNA strand transfer. Nature 2010, 464, 232-236. [CrossRef]

23. Mackler, R.M.; Lopez, M.A., Jr.; Yoder, K.E. Assembly and Purification of Prototype Foamy Virus Intasomes. J. Vis. Exp. 2018, 133, e57453. [CrossRef]

24. Andrake, M.D.; Ramcharan, J.; Merkel, G.; Zhao, X.Z.; Burke, T.R., Jr.; Skalka, A.M. Comparison of metal-dependent catalysis by HIV-1 and ASV integrase proteins using a new and rapid, moderate throughput assay for joining activity in solution. AIDS Res. Ther. 2009, 6, 14. [CrossRef]

25. Mackler, R.M.; Lopez, M.A.; Osterhage, M.J.; Yoder, K.E. Prototype foamy virus integrase is promiscuous for target choice. Biochem. Biophys. Res. Commun. 2018, 503, 1241-1246. [CrossRef]

26. Miller, M.D.; Bor, Y.C.; Bushman, F. Target DNA capture by HIV-1 integration complexes. Curr. Biol. 1995, 5, 1047-1056. [CrossRef]

27. Lopez, M.A., Jr.; Mackler, R.M.; Altman, M.P.; Yoder, K.E. Detection and Removal of Nuclease Contamination during Purification of Recombinant Prototype Foamy Virus Integrase. J. Vis. Exp. JoVE 2017, 130, e56605. [CrossRef]

28. Lopez, M.A., Jr.; Mackler, R.M.; Yoder, K.E. Removal of nuclease contamination during purification of recombinant prototype foamy virus integrase. J. Virol. Methods 2016, 235, 134-138. [CrossRef]

29. Valkov, E.; Gupta, S.S.; Hare, S.; Helander, A.; Roversi, P.; McClure, M.; Cherepanov, P. Functional and structural characterization of the integrase from the prototype foamy virus. Nucleic Acids Res. 2009, 37, 243-255. [CrossRef]

30. Wolfe, A.L.; Felock, P.J.; Hastings, J.C.; Blau, C.U.; Hazuda, D.J. The role of manganese in promoting multimerization and assembly of human immunodeficiency virus type 1 integrase as a catalytically active complex on immobilized long terminal repeat substrates. J. Virol. 1996, 70, 1424-1432. [CrossRef] [PubMed]

31. Jones, N.D.; Mackler, R.M.; Lopez, M.A., Jr.; Baltierra-Jasso, L.E.; Altman, M.P.; Senavirathne, G.; Yoder, K.E. Prototype foamy virus intasome aggregation is mediated by outer protein domains and prevented by protocatechuic acid. Sci. Rep. $2019,9,132$. [CrossRef] [PubMed]

32. Kotlar, R.M.; Jones, N.D.; Senavirathne, G.; Gardner, A.M.; Messer, R.K.; Tan, Y.Y.; Rabe, A.J.; Fishel, R.; Yoder, K.E. Retroviral prototype foamy virus intasome binding to a nucleosome target does not determine integration efficiency. J. Biol. Chem. 2021, 296, 100550. [CrossRef] [PubMed]

33. Maertens, G.N.; Hare, S.; Cherepanov, P. The mechanism of retroviral integration from X-ray structures of its key intermediates. Nature 2010, 468, 326-329. [CrossRef]

34. Jones, N.D.; Lopez, M.A., Jr.; Hanne, J.; Peake, M.B.; Lee, J.B.; Fishel, R.; Yoder, K.E. Retroviral intasomes search for a target DNA by $1 \mathrm{D}$ diffusion which rarely results in integration. Nat. Commun. 2016, 7, 11409. [CrossRef]

35. Maskell, D.P.; Renault, L.; Serrao, E.; Lesbats, P.; Matadeen, R.; Hare, S.; Lindemann, D.; Engelman, A.N.; Costa, A.; Cherepanov, P. Structural basis for retroviral integration into nucleosomes. Nature 2015, 523, 366-369. [CrossRef] [PubMed] 
36. Benleulmi, M.S.; Matysiak, J.; Henriquez, D.R.; Vaillant, C.; Lesbats, P.; Calmels, C.; Naughtin, M.; Leon, O.; Skalka, A.M.; Ruff, M.; et al. Intasome architecture and chromatin density modulate retroviral integration into nucleosome. Retrovirology 2015, 12, 13. [CrossRef] [PubMed]

37. Li, M.; Lin, S.; Craigie, R. Outer domains of integrase within retroviral intasomes are dispensible for catalysis of DNA integration. Protein Sci. 2016, 25, 472-478. [CrossRef]

38. Pasi, M.; Mornico, D.; Volant, S.; Juchet, A.; Batisse, J.; Bouchier, C.; Parissi, V.; Ruff, M.; Lavery, R.; Lavigne, M. DNA minicircles clarify the specific role of DNA structure on retroviral integration. Nucleic Acids Res. 2016, 44, 7830-7847. [CrossRef] [PubMed]

39. Qi, X.; Vargas, E.; Larsen, L.; Knapp, W.; Hatfield, G.W.; Lathrop, R.; Sandmeyer, S. Directed DNA shuffling of retrovirus and retrotransposon integrase protein domains. PLoS ONE 2013, 8, e63957. [CrossRef]

40. Wilson, M.D.; Renault, L.; Maskell, D.P.; Ghoneim, M.; Pye, V.E.; Nans, A.; Rueda, D.S.; Cherepanov, P.; Costa, A. Retroviral integration into nucleosomes through DNA looping and sliding along the histone octamer. Nat. Commun. 2019, 10, 4189. [CrossRef]

41. Yin, Z.; Lapkouski, M.; Yang, W.; Craigie, R. Assembly of prototype foamy virus strand transfer complexes on product DNA bypassing catalysis of integration. Protein Sci. 2012, 21, 1849-1857. [CrossRef]

42. Vanderlinden, W.; Brouns, T.; Walker, P.U.; Kolbeck, P.J.; Milles, L.F.; Ott, W.; Nickels, P.C.; Debyser, Z.; Lipfert, J. The free energy landscape of retroviral integration. Nat. Commun. 2019, 10, 4738. [CrossRef] [PubMed]

43. Engelman, A.N.; Cherepanov, P. Retroviral intasomes arising. Curr. Opin. Struct. Biol. 2017, 47, 23-29. [CrossRef]

44. Hare, S.; Maertens, G.N.; Cherepanov, P. 3'-processing and strand transfer catalysed by retroviral integrase in crystallo. EMBO J. 2012, 31, 3020-3028. [CrossRef]

45. Engelman, A.; Craigie, R. Efficient magnesium-dependent human immunodeficiency virus type 1 integrase activity. J. Virol. 1995, 69, 5908-5911. [CrossRef] [PubMed]

46. Ellison, V.; Abrams, H.; Roe, T.; Lifson, J.; Brown, P. Human immunodeficiency virus integration in a cell-free system. J. Virol. 1990, 64, 2711-2715. [CrossRef] [PubMed]

47. Farnet, C.M.; Haseltine, W.A. Integration of human immunodeficiency virus type 1 DNA in vitro. Proc. Natl. Acad. Sci. USA 1990, 87, 4164-4168. [CrossRef] [PubMed]

48. Baltierra-Jasso, L.E.; Jones, N.D.; Ballandras-Colas, A.; Engelman, A.N.; Fishel, R.; Yoder, K.E. The mouse mammary tumor virus intasome exhibits distinct dynamics on target DNA. bioRxiv 2021, 468995. [CrossRef]

49. Bonnet, I.; Biebricher, A.; Porte, P.L.; Loverdo, C.; Benichou, O.; Voituriez, R.; Escude, C.; Wende, W.; Pingoud, A.; Desbiolles, P. Sliding and jumping of single EcoRV restriction enzymes on non-cognate DNA. Nucleic Acids Res. 2008, 36, 4118-4127. [CrossRef]

50. Serrao, E.; Ballandras-Colas, A.; Cherepanov, P.; Maertens, G.N.; Engelman, A.N. Key determinants of target DNA recognition by retroviral intasomes. Retrovirology 2015, 12,39. [CrossRef]

51. Lesbats, P.; Serrao, E.; Maskell, D.P.; Pye, V.E.; O’Reilly, N.; Lindemann, D.; Engelman, A.N.; Cherepanov, P. Structural basis for spumavirus GAG tethering to chromatin. Proc. Natl. Acad. Sci. USA 2017, 114, 5509-5514. [CrossRef]

52. Cherepanov, P.; Maertens, G.; Proost, P.; Devreese, B.; Van Beeumen, J.; Engelborghs, Y.; De Clercq, E.; Debyser, Z. HIV-1 integrase forms stable tetramers and associates with LEDGF/p75 protein in human cells. J. Biol. Chem. 2003, 278, 372-381. [CrossRef]

53. Shun, M.C.; Raghavendra, N.K.; Vandegraaff, N.; Daigle, J.E.; Hughes, S.; Kellam, P.; Cherepanov, P.; Engelman, A. LEDGF/p75 functions downstream from preintegration complex formation to effect gene-specific HIV-1 integration. Genes Dev. 2007, 21, 1767-1778. [CrossRef] [PubMed]

54. Linial, M. Why aren't foamy viruses pathogenic? Trends Microbiol. 2000, 8, 284-289. [CrossRef]

55. Bhatt, V.; Shi, K.; Salamango, D.J.; Moeller, N.H.; Pandey, K.K.; Bera, S.; Bohl, H.O.; Kurniawan, F.; Orellana, K.; Zhang, W.; et al. Structural basis of host protein hijacking in human T-cell leukemia virus integration. Nat. Commun. 2020, 11, 3121. [CrossRef]

56. Passos, D.O.; Li, M.; Yang, R.; Rebensburg, S.V.; Ghirlando, R.; Jeon, Y.; Shkriabai, N.; Kvaratskhelia, M.; Craigie, R.; Lyumkis, D. Cryo-EM structures and atomic model of the HIV-1 strand transfer complex intasome. Science 2017, 355, 89-92. [CrossRef] [PubMed]

57. Yin, Z.; Shi, K.; Banerjee, S.; Pandey, K.K.; Bera, S.; Grandgenett, D.P.; Aihara, H. Crystal structure of the Rous sarcoma virus intasome. Nature 2016, 530, 362-366. [CrossRef] [PubMed] 